\title{
The Architectural Background of Trinity Episcopal Church
}

Loren N. Horton

THE FIRST EPISCOPAL CHURCH SERVICE IN IOWA CITY TOOK place in November 1841, with the Reverend Zachariah Goldsmith of Davenport as priest in charge. Since there was no building for the small congregation at that time, the Methodist Church was used. No further Episcopal services were held until 1847 when the Reverend Alfred Lauderback of Davenport held missionary services.

Attempts to organize a regular parish began in 1851 under the leadership of the Reverend C. C. Townsend, and these plans came to fruition on 7 March 1853 when Trinity Parish was incorporated. On 17 August that year the General Convention of the Protestant Episcopal Church in the United States of America approved of the establishment of the Diocese of Iowa. For many years Trinity Parish did not have a building of its own, and met for services in such other buildings as the Methodist Church, the Lutheran Church, the Territorial Capitol building, the Universalist Society building, and in 1862 the congregation began meeting regularly in the "Atheneum" building on the northwest corner of Burlington and Dubuque Streets. ${ }^{1}$

On 27 July 1868 the Vestry purchased Lots 7 and 8 of

'Charles and Miriam Righter, Trinity Episcopal Church (Iowa City: privately printed, 1971), 1-3; Samuel N. Watson, History of Trinity Parish (Iowa City: privately printed, 1893), 4-8: C. Compton Burnett, The Parish Year Book of Trinity Church (Iowa City: privately printed, 1880), 3; Russia G. Harris, ed., One Hundred Years of the Episcopal Church in Iowa City (Iowa City: privately printed, 1941), 11-19. 
Block 62 in the original plat of Iowa City, so that they might build their own church and rectory. ${ }^{2}$ For the next three years funds were accumulated to pay for the new building, and discussions were held about a suitable design. The people in charge turned to a published book by Richard Upjohn for help. This book had been published in 1852 and was very popular in the East with Episcopal congregations of limited resources. At least seven churches in the Midwest resemble the design, and many more have features that were probably adapted from it. Different materials were used and modifications took place freely, both by Upjohn and by those who purchased his book. Upjohn's sample church, which was designed to cost $\$ 3000$, was ecclesiastically correct and contained all of the features that Episcopal vestries normally considered necessary. Cost was flexible according to local conditions, and the use of vertical board and batten construction became a sort of trademark for these Upjohn-derived churches. ${ }^{3}$

According to Upjohn's own records only one church in Iowa was designed by him. That was Hope Church, Fort Madison, now called St. Luke's. Upjohn's correspondence indicates that plans were given for that building on 1 May $1855 .{ }^{4}$ However, the records of the church indicate that the plans were never used.

Ordered that the Chairman be directed to return the thanks of the members of Hope Church to Mr. Upjohn, Architect of New York, for the plan of a Church building furnished by him for said Church, and advise him, that inasmuch as the said plan is drawn for a building of different materials than is intended to be erected in this place, and as the cost would greatly exceed the means subscribed for said building, the plan was not adopted, and now remains in the lands of Rev. Mr. Adderly, Burlington, subject to the order of Mr. Upjohn.

On Motion.

Ordered, That the Secretary of this meeting procure from

${ }^{2}$ Original deed, Trinity Parish Archives, Iowa City, Iowa.

${ }^{3}$ Richard Upjohn, Upjohn's Rural Architecture (New York: G. P. Putnam's, 1852).

"Everard M. Upjohn, Richard Upjohn: Architect and Churchman (New York: Columbia University Press, 1939), 120, 210. 
Mr. Bapett, Architect, Burlington, Iowa, a plan for a Church building at this place similar to the one recently drawn for the Church at Fairfield, so that the cost of said building shall not exceed eighteen hundred dollars. ${ }^{5}$

Richard Upjohn was born in Shaftesbury, Dorset, England on January 22, 1802. At the age of seventeen he was apprenticed to a cabinetmaker and made his living at that trade until 1829. It is possible that he drew on some familiarity with his father's work as a surveyor to aid him in his first jobs in drafting offices, for he had no training in an architect's office. Upjohn emigrated to the United States in 1829 and after a short stay in New York City, took up residence in Manlius, New York where his brother-in-law already lived. After a year of trying to eke out a living there he moved on to New Bedford, Massachusetts. His brother lived there, and the city was the center of a flourishing whaling industry. Apparently he was employed as a draftsman by Samuel Leonard, but he was also a charter member of the Mechanic's Association as a carpenter in 1833. By 1833 Upjohn seems to have felt that he had gained enough skill to open his own office and advertise that he could execute architectural plans and elevations.

The first building that can be undoubtedly attributed to the design of Richard Upjohn is the Isaac Farrar house in Bangor, Maine. This home was of sufficiently good quality to bring him other commissions, among them the Samuel Farrer house in Bangor, Maine. Both of the latter houses were finished after Upjohn had moved to Boston

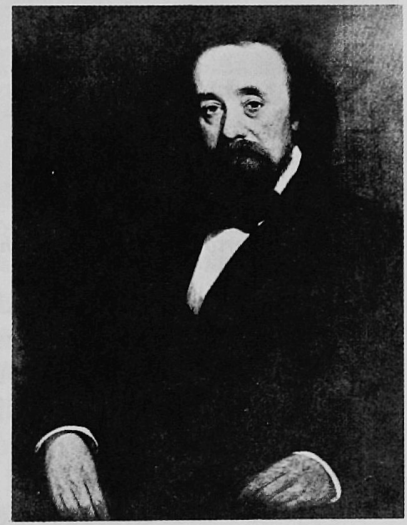

From Everard M. Upjohn, Richard Upjohn: Architect and Churchman

Richard Upjohn

${ }^{5}$ Vestry Minutes, Hope Church, Fort Madison, Iowa, 26 November 1855 . The building was erected in 1857 at an estimated cost of $\$ 4000$. 


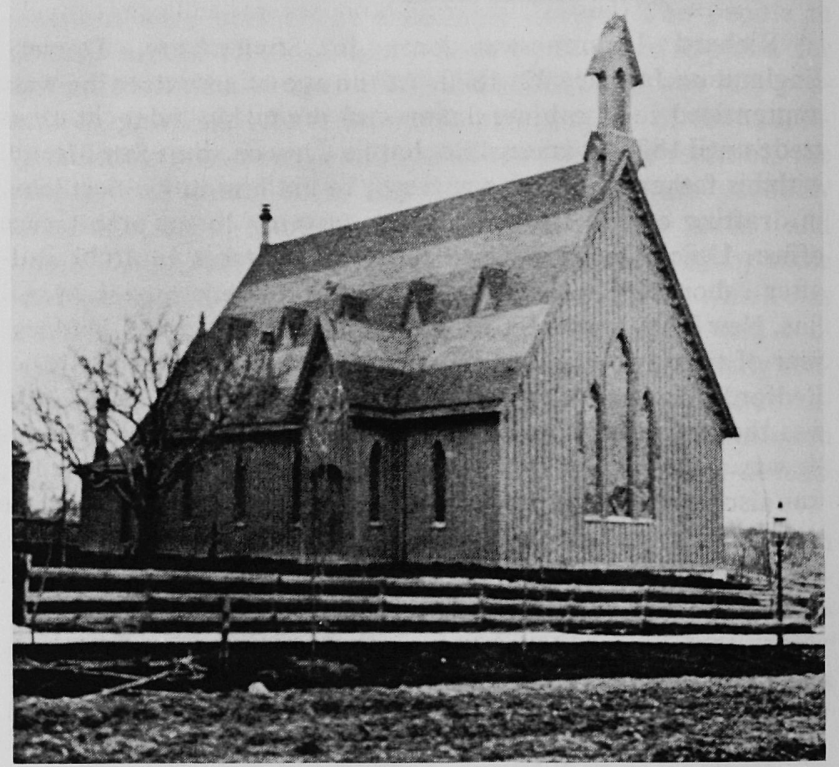

courtesy Charles B. Righter

Exterior view of Trinity Church, nineteenth century

in 1834 , and in 1839 he moved to New York City where he lived the remainder of his life. These early designs were in the fashionable styles of the day, Georgian and Classical Revival. And although he continued to design residences and other sorts of buildings throughout his career, it is for his church designs that he is best known.

Upjohn's first churches were in the early Gothic style, but his mature period churches were mainly in Perpendicular or Early English Gothic. Originally an Anglican, he was a devout Episcopalian and consciously used his architectural skills to design masterpieces that demonstrated his High Church lean- 
ings and his affiliations with the Oxford Movement. It was even rumored that he refused to draw plans for other denominations, because he did not consider them entitled to good architecture. This is not true, and several college chapels, Presbyterian churches, and even Congregational churches, surely far removed from Upjohn's liturgical preferences, were designed by him. Among the most notable Episcopal churches attributed to Upjohn are: St. John's Church, Bangor, Maine; Trinity Church, New York City; Church of the Ascension, New York City; Christ Church, Brooklyn, New York; Grace Church, Providence, Rhode Island; St. Paul's Church, Buffalo, New York; and St. Thomas' Church, New York City. Of all of these the most famous is Trinity Church, New York City, which is also one of his earliest efforts, having been built between 1839 and $1846 .^{\circ}$

Many Episcopal congregations requested suitable designs from Upjohn. Most of them were unable to afford his fees, and he was sympathetic to these people. To accommodate them he published a book in 1852 entitled Upjohn's Rural Architecture. It contained prepared drawings for a small church and for a chapel, and also had complete specifications. Poorer parishes could then use these ready-made drawings, hire a builder, and have a tastefully designed church without being burdened with exhorbitant fees to a designer. The book sold for \$5, and as Upjohn said in the preface, “. . . any intelligent mechanic will be able to carry out the design." ?

No evidence has been located to indicate that Richard Upjohn was retained as the architect for building Trinity Church, Iowa City. But the design is similar to buildings which are verifiably of his design. Moreover, many smaller churches were built from the general plans in the book. As Wayne Andrews commented: "For country parishes that could not afford stone or even brick and plaster, he [Upjohn] published a handbook of wooden churches that was a godsend to carpenters." ${ }^{8}$ That this indirect source of the building plan is prob-

'Everard M. Upjohn, Richard Upjohn: Architect and Churchman, 18-188.

'Richard Upjohn, Upjohn's Rural Architecture, preface.

-Wayne Andrews, Architecture, Ambition and Americans (Glencoe: The Free Press, 1964), 127. 


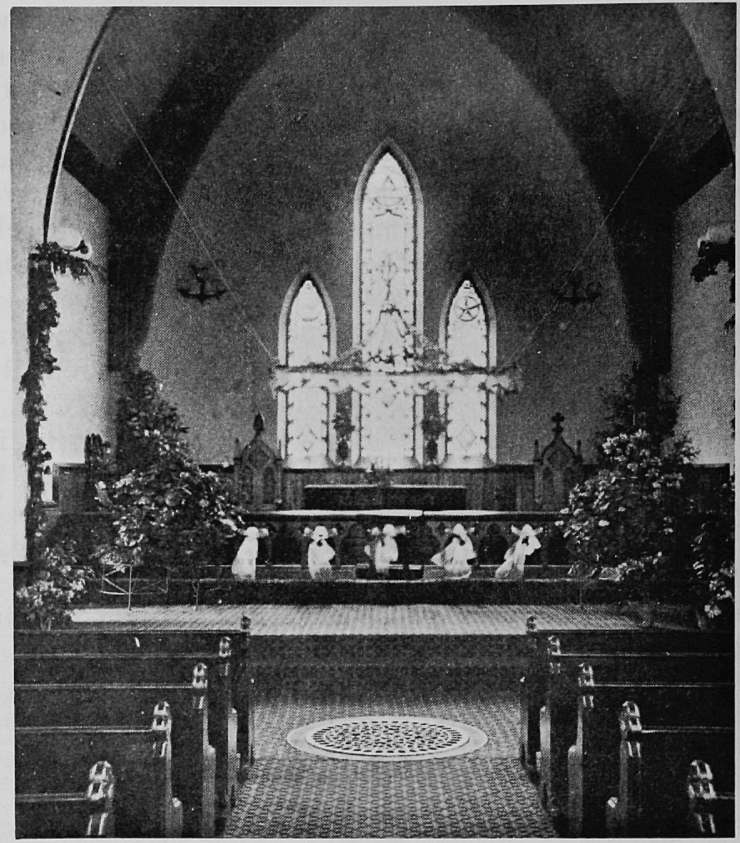

courtesy Charles B. Righter

Interior view of Trinity Church, nineteenth century

ably correct is indicated by an early history of Trinity Church: "On January 16th, 1872, the plan of the Church was selected, being a modification of one of Upjohn's plans for Gothic Churches;..."9 Other midwestern churches provably designed by Upjohn resemble it strongly, and a Wisconsin church is almost an exact duplicate. The illustration of the original drawing by Upjohn in his 1852 plan book also indicates the strong similarity to Trinity Church. ${ }^{10}$

The local newspaper reported on 26 April 1871 that:

${ }^{9}$ Watson, History of Trinity Parish, 8.

${ }^{10}$ Everard M. Upjohn, Richard Upjohn, Figure 68. While most observers agree that Trinity Episcopal Church, Iowa City, is in the Gothic Revival style, Marcus Whiffen states that: "Richard Upjohn, whose Trinity, New York, represents the Gothic Revival at its most correct, 




Trinity Church as it looks today

Photograph by Loren N. Horton

The corner stone of the New Episcopal church in this city will be laid on Thursday afternoon next by Bishop Lee. The public are cordially invited to attend the ceremonies. Trinity church will in all probability be completed and consecrated in the month of July next. It is to be a frame Gothic Edifice, one of the prettiest churches of that style in Iowa, and will seat about three hundred persons. ${ }^{11}$

had a line in small country churches of wood that are at least as much Stick Style as they are Gothic." See Marcus Whiffen, American Architecture Since 1780 (Cambridge: The M. I. T. Press, 1969), 111. The Diocese of Iowa has always considered it to be Gothic, as is indicated by the 1871 Convention Journal. "The building is situated on a fine corner lot, nearly one hundred and sixty feet square, central to the city and the parish. The church is a Gothic frame, a very durable and elegant structure. Both exterior and interior will be beautiful in finish and of harmonious proportions." See Journal of the Eighteenth Annual Convention of the Protestant Episcopal Church in the Diocese of Iowa (Davenport: Griggs, Watson and Day, 1871), 40.

${ }^{11}$ Iowa State Press (Iowa City), 26 April 1871. 
Bishop Henry Washington Lee consecrated the church building on 3 April 1872 and stated:

It is unnecessary for me to speak particularly of the fitness and beauty of this new sanctuary, for it bears its own testimony, as we are now assembled within its walls. It is one of the architectural gems of the West, and does great credit to the parish and to the Diocese. ${ }^{12}$

Trinity Episcopal Church, Iowa City, is of frame construction and uses the vertical board and batten construction technique. It is of the Gothic Revival style, or the type commonly known as carpenter, cottage, or pseudo-perpendicular. Trefoil ornamentation in relief appears on the facade, and three lancet arch windows pierce the wall over the front door. There are also four lancet arch windows along the sides of the church, indicating the bays. Five clerestory windows echo the bays, and the battens terminate in a repetition of the lancet points under the eaves. A dentil course is used in place of vergeboard trim. The face of the narthex repeats the facade design on a smaller scale. A projection, a sort of an open bellcote or a semi-flèche substitutes for a steeple. It is also pierced by a lancet arch and the dentillation repeats the narthex and facade trim. A recessed trefoil cusp is used here in place of the relief trefoil ornamentation on the rest of the building. The botonée supports a large botonée cross. Transepts bisect the cruciform-shaped building between the first and third bays on the narthex end. Relief trefoil ornaments and dentillation repeat the design of the facade, narthex, and bellcote. The two side windows in each transept are lancet arched, but an elliptical arch is used to fill in the area on the outward ends. The first four bays of the building are the nave, the fifth is the choir, while a projection to the north furnishes the space for the chancel, and a stained glass window with a lancet arch pierces the non-apse north gable of the south-to-north axis church. A Parish Hall was added in a L extending west from

${ }^{12}$ Journal of the Nineteeth Annual Convention of the Protestant Episcopal Church in the Diocese of Iowa (Davenport: Griggs, Watson and Day, 1872), 19. 
the north end of the church. This joined the 1878 Rectory which sat on the block just to the west of the church. However, in 1971 the old Rectory was removed and an addition made to the Parish Hall, designed by G. B. Cox of Bettendorf, Iowa. The pattern now is a quadrangle and the west side of the church may only be seen from the small courtyard in the middle of the quadrangle. The south wing of this addition extends across the facade of the church at the lower level, but it has been constructed in a style sympathetic to the original, and the Gothic details have been repeated, not obscured. The trefoil motif is found repeatedly in both the old and the new portions of the total complex, in various forms, and it is fitting to a parish church dedicated to the Trinity.

The interior of Trinity Church continues the Gothic Revival style of the exterior. The main roof of the nave is steeply pitched, pierced by clerestory windows, and supported by six heavy beams whose butts divide the side walls between each lancet arch window. All windows are stained glass. An elaborately carved, dark-wood reredos stands in front of the large, traceried, stained-glass apse window behind the Altar. Darkwood pews are arranged in the nave in the traditional center aisle and side aisle pattern of medieval Gothic churches. The interior walls are plastered, alcoves on each side of the nave at the second bay contain small chapel altars, and the choir is flanked by the organ on the right wall and its pipes directly across on the left wall, behind the choir pews. The lancet arch design is repeated in the curve of the beams and in the opening to the Sanctuary. The Bishop's Chair sits to the left of the Altar. Trefoil and quatrefoil carvings decorate the woodwork throughout the interior, and all of the woodwork is a uniform dark brown.

Trinity Episcopal Church is the only Gothic Revival style building in Iowa City that employs vertical board and battens, a frequently-used construction form of the style. For this reason it is significant as an extant example of a common design and building technique of the mid-19th century Midwest. The congregation has been intimately connected with the history of Iowa City and the University of Iowa since the inception of 


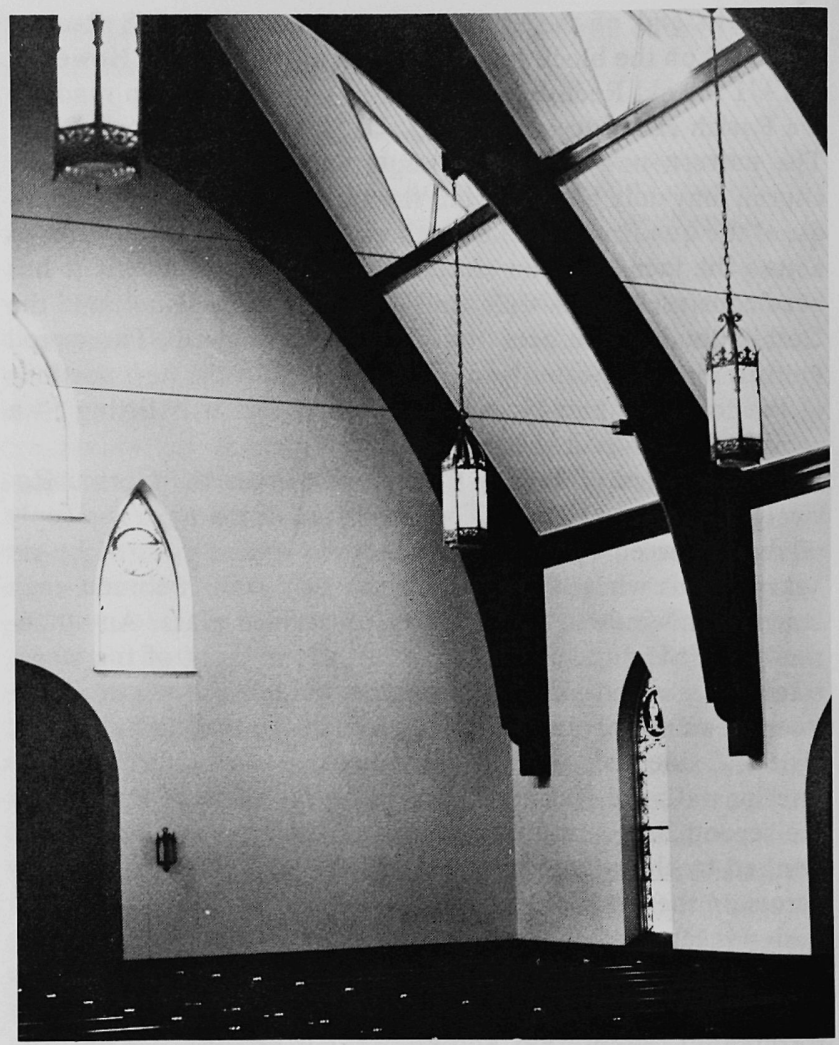

Photograph by Loren N. Horton

Interior view of Trinity Church, 1974

each institution. Three university presidents have been parishioners, and one Rector of Trinity Parish also served as president of the university. That was Silas Totten, 1859-1862. The building and the congregation which it houses are an integral part of the social fabric of the community, and the building is a visual example of the 19th century heritage of the town. 
Copyright of Annals of Iowa is the property of State of Iowa, by \& through the State Historical Society of Iowa and its content may not be copied or emailed to multiple sites or posted to a listserv without the copyright holder's express written permission. However, users may print, download, or email articles for individual use. 